\title{
CORRELATION STUDY OF SERUM CALCIUM LEVELS AND SERUM CARTILAGE OLIGOMERIC MATRIX PROTEIN LEVELS IN RHEUMATOID ARTHRITIS PATIENTS IN BANDUNG, INDONESIA
}

\author{
NYI MEKAR SAPTARINI ${ }^{1,2 *}$, MARLIA SINGGIH WIBOWO ${ }^{1}$, TUTUS GUSDINAR $^{1}$
}

${ }^{1}$ Department of Pharmacochemistry, School of Pharmacy, Institut Teknologi Bandung, Jl Ganesha 10, West Java 40132, Indonesia. ${ }^{2}$ Department of Pharmaceutical Analysis and Medicinal Chemistry, Faculty of Pharmacy, Universitas Padjadjaran, Jl Raya Bandung Sumedang km 21, West Java 45363, Indonesia. Email: nyi.mekar@unpad.ac.id

Objective: This study was designed is to determine the correlation between serum calcium level and serum cartilage oligomeric matrix protein (COMP) level in Indonesian patients with rheumatoid arthritis (RA).

Subjects and Methods: The subjects are patients who visit the rheumatology clinic at a government hospital in Bandung, Indonesia. Serum calcium level was determined by a complexometric method, and the serum COMP level was determined by enzyme-linked immunosorbent assay. Statistical analysis was performed with R software.

Results: The serum calcium level was $82.24 \pm 44.82 \mathrm{mg} / \mathrm{mL}$ in RA patients and $99.04 \pm 60.56 \mathrm{mg} / \mathrm{mL}$ in normal controls. The serum COMP level was $843.80 \pm 35.79 \mathrm{ng} / \mathrm{ml}$ in RA patients and $830.00 \pm 48.92 \mathrm{ng} / \mathrm{ml}$ in normal controls.

Conclusion: There is no correlation between serum calcium level and serum COMP levels in RA patients ( $\mathrm{p}=0.967$ and rho=0.006).

Keywords: Autoimmune disease, Rheumatoid arthritis monitoring, Complexometric, Enzyme-linked immunosorbent assay, Indonesia

(C) 2017 The Authors. Published by Innovare Academic Sciences Pvt Ltd. This is an open access article under the CC BY license (http://creativecommons. org/licenses/by/4. 0/) DOI: http://dx.doi.org/10.22159/ajpcr.2017.v10i11.18493

\section{INTRODUCTION}

Rheumatoid arthritis (RA) is an autoimmune disease characterized by erosive arthritis in the synovial joints on both sides of the body [1]. The global prevalence of RA was $0.24 \%$, with no discernible change from 1990 to 2010 [2]; the prevalence in Indonesia was $0.1-0.3 \%$ in 2009 [3]. Early diagnosis and treatment of RA are essential to prevent joint deformation [4].

In Indonesia, RA diagnoses are based on the clinical manifestations of the disease, which are usually observed late in the disease's progression. Therefore, it is necessary to develop a new method for early detection of RA. One example of such a method involves the use of cartilage oligomeric matrix protein (COMP). This is an extracellular matrix protein primarily present in cartilage and it plays a role in the organization of collagen fibrils [5] which can used as a potential biomarker to support RA diagnosis [6], as RA patients tend to have an increased risk of bone loss and fractures [7], due to inactivity of joint function as well as joint inflammation [8]. Furthermore, glucocorticoid, which is prescribed to RA patients, has been shown to trigger significant bone loss. In this study, we measured the correlation of serum calcium levels, which represent the level of bone loss, and serum COMP levels in RA patients.

\section{SUBJECTS AND METHODS}

\section{Subjects}

Subjects were recruited by the consecutive sampling method after being given sufficient explanation and signing an informed consent form. They were then divided into two groups: RA patients and normal controls [9]. This study was approved by the Health Research Ethics Committee of the Dr. Hasan Sadikin Hospital, Indonesia.

The inclusion criteria are [9]:

a. RA patients of the Rheumatology Clinic at a Government Hospital in Bandung, Indonesia b. RA patients who met at least four of the clinical criteria from the 2010 RA classification criteria [10], based on examination by a rheumatologist without serology examination

c. RA patients willing to participate in this study and who signed an informed consent form

d. Patients over 18 years of age.

The exclusion criteria are [9]:

a. Patients who are uncooperative

b. Patients with a history of drug abuse including alcoholism

c. Patients with any other major medical disorder, including diabetes mellitus, hypertension, chronic obstructive pulmonary disease, acute or chronic liver disease, acute or chronic kidney disease, tuberculosis, and systemic lupus erythematosus.

All patients were interviewed regarding their age, disease duration, how many joints had definite clinical synovitis (swelling), symmetrical arthritis, pain duration in the morning, drug therapy, medical treatment undergone to reduce the pain such as surgery, and genealogy [9].

\section{Methods}

Serum preparation

Blood samples were collected from patients between March and May 2016; samples were taken from a peripheral vein and placed in a tube without ethylenediaminetetraacetic acid. The samples were allowed to stand for 30 minutes to form a coagulant and then centrifuged at $3000 \mathrm{rpm}$ for 15 minutes. The serum was separated from the sediment and stored at $-80^{\circ} \mathrm{C}$.

Determination of serum calcium level

Serum calcium levels were measured using a modified complexometric method with a murexide reagent [11]. A total of $0.2 \mathrm{~mL}$ of serum or calcium standard solution was added to $0.8 \mathrm{~mL}$ of distilled water and 
$0.5 \mathrm{~mL}$ of murexide reagent and was thoroughly mixed. The mixture was allowed to stand for 5 minutes at room temperature to allow gas bubbles to rise and was then measured within the next 10 minutes using a spectrophotometer at $510 \mathrm{~nm}$. The zero absorbance was set using distilled water as the blank solution.

\section{Preparation of murexide reagent}

About $4 \mathrm{mg}$ of murexide (ammonium purpurate) was dissolved in $0.5 \mathrm{~mL}$ distilled water. $1.5 \mathrm{~mL} 3.75 \mathrm{~N}$ potassium hydroxide and $5.0 \mathrm{~mL}$ distilled water were then added and thoroughly mixed.

Preparation of calcium standard solution: $0.2497 \mathrm{~g}$ of calcium carbonate was dissolved in $0.5 \mathrm{~mL}$ concentrated hydrochloric acid and was diluted to $100 \mathrm{~mL}$ with distilled water. The final concentration was $1 \mathrm{mg} / \mathrm{mL}$.

\section{Determination of serum COMP levels}

Serum COMP levels were determined using the procedure described in The Human COMP/TSP5 enzyme-linked immunosorbent assay Pair Set (SEK10173) purchased from Sino Biological Inc. (USA). The method utilizes a monoclonal antibody specific for COMP/TSP5 coated on a 96-well plate. Standards and samples were added to the wells, and any COMP/TSP5 present bonded with the immobilized antibody. The wells were washed and a biotinylated rabbit anti-COMP polyclonal antibody was then added, producing an antibody-antigen-antibody "sandwich." Streptavidin-horseradish peroxidase and tetramethylbenzidine substrate solutions were then loaded to produce color, and the absorbance levels were measured using a spectrophotometer at $450 \mathrm{~nm}$.

\section{Statistical analysis}

The correlation between serum calcium levels and serum COMP levels was analyzed using the R software.

\section{RESULTS}

There were 30 RA patients who met the inclusion criteria with a mean age of $43.77 \pm 2.04$ years old (range 20-64 years) for RA patients and $41.23 \pm 2.46$ years old (range 21-60 years) for normal controls (Fig. 1).

Regarding the condition of the patients, the interview data showed that the shortest disease duration was 3 months and the longest was 204 months. The most common disease duration for RA was 1-12 months (Fig. 2) with an average of $56.13 \pm 49.24$ months. In addition to a wide range of disease duration, the data also showed that the conditions of the patients varied. Most of the RA patients (80\%) experienced joint pains for a minimum of 3-9 months before undergoing a medical checkup, while $16.67 \%$ of the patients had bone deformities due to the lack of early treatment. Furthermore, all patients felt pain in the small joints of the hands, wrists, elbows, knees, and ankles, in accordance with the common symptoms of RA [10], although joint stiffness was worse in the morning and evening than during the day. Finally, the interview data showed that $16.67 \%$ of the patients suffered hand deformities that reduced their grip strength and complicated their daily activities; $86.67 \%$ of the patients who experienced knee pain also experienced difficulties in walking for long periods, which interfered with their daily activities.

The results show that the serum calcium level was $82.24 \pm 44.82 \mathrm{mg} / \mathrm{mL}$ in RA patients and $99.04 \pm 60.56 \mathrm{mg} / \mathrm{mL}$ in the normal controls. At the same time, the serum COMP level was $843.80 \pm 35.79 \mathrm{ng} / \mathrm{ml}$ in RA patients and $830.00 \pm 48.92 \mathrm{ng} / \mathrm{ml}$ in the normal controls. Statistical analysis shows that there is no correlation between serum calcium level and serum COMP level in RA patients ( $\mathrm{p}=0.967$ and $\mathrm{rho}=0.006)$.

\section{DISCUSSIONS}

There were a total of 80 RA patients registered at the hospital between March and May 2016, but only 30 met the inclusion criteria: 26 were women (86.67\%) and four were men (13.33\%). This result is consistent

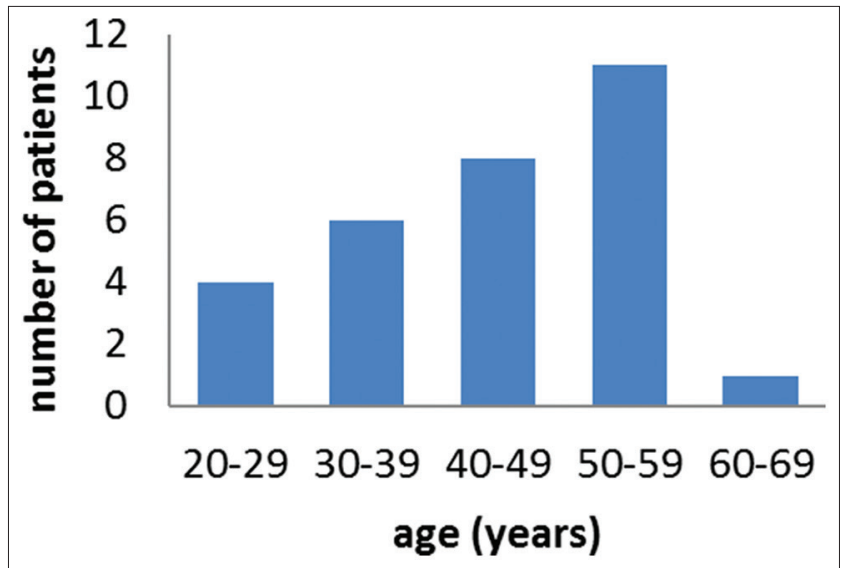

Fig. 1: Distribution of patients according to age groups $(n=30)$

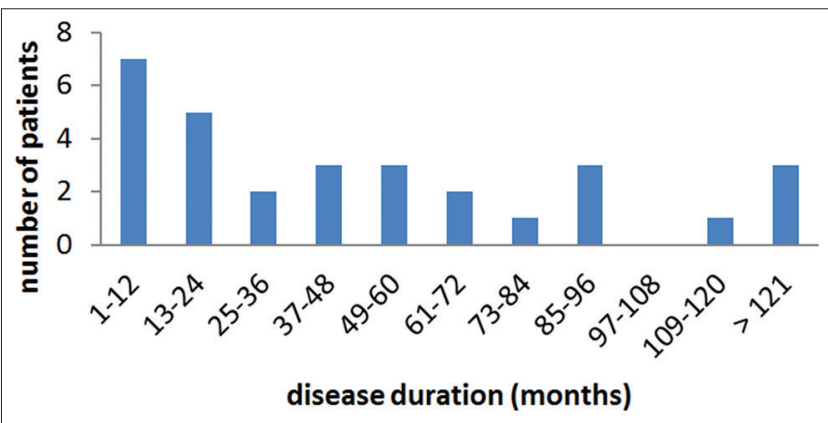

Fig. 2: Distribution of patients according to disease duration $(n=30)$

with literature which states that the incidence of RA in women is seven times higher than in men, i.e. $87.43 \%$ [12] and $79.60 \%$ [13]. This is due to the effect of hormones, especially estrogen which affects autoimmune diseases such as RA, causing a higher RA incidence in women $[14,15]$. Estrogen plays a role in maturation of growing bone and prevention of bone loss. At the age above 30 years, female estrogen tends to decrease, which makes estrogen deficiency and triggers an imbalance of bone remodeling activity [16].

The results also show that the highest RA incidence was among patients 50-59 years of age (Fig. 1). This is consistent with our previous study conducted at the same hospital between December 2014 and January $2015(n=24)$ [9]. Furthermore, the interview data show that the patients visited a doctor only after abnormal symptoms in the body. Their strenuous activities caused severe pain; and to cope with the pain, they consumed analgesics such as paracetamol or diclofenac sodium. This shows a lack of awareness of RA symptoms among the general public. Many Indonesians consider RA as a disease only the elderly suffer, so there is a lack of awareness regarding the health monitoring of joint pains among people under 50 years old. However, in our previous study, patients with higher educational levels showed a higher awareness of health monitoring $[9,17]$.

Determination of the serum calcium level showed that it was lower in RA patients than in the normal controls, a result consistent with literature [18]. Calcium absorption in RA is reduced due to a primary malabsorptive process, but the mechanism is still unknown. One possibility is that an alteration in the oxidative metabolism leads to a disruption in the intracellular ionic environment and altered calcium levels [19]. This decreased calcium level in RA patients is an integral feature of RA [18]. However, some authors suggest that hypocalcemia is the result of the drugs used in RA treatment and may not be due to the disease itself [19]. Glucocorticoid therapy which given to RA patients can lead to bone loss. Glucocorticoids inhibit the calcium resorption in the renal tubules and calcium absorption in the gut through Vitamin 


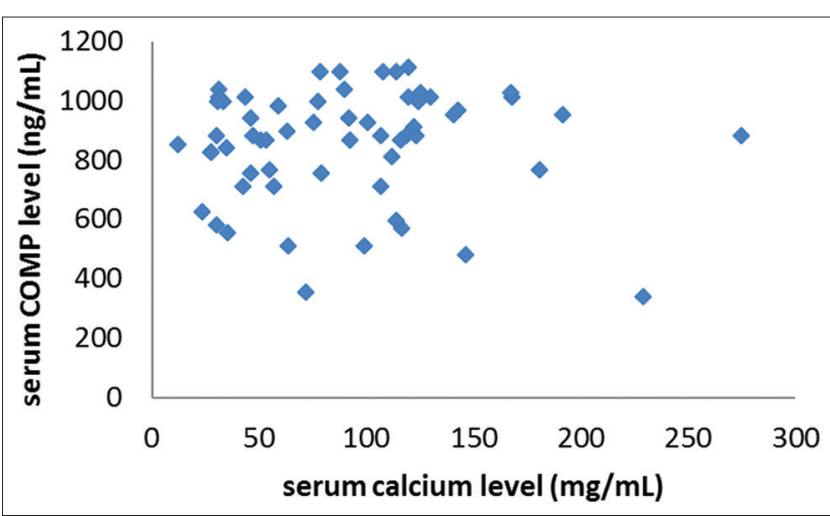

Fig. 3: Distribution of serum calcium level to serum cartilage oligomeric matrix protein level $(n=30)$

D-dependent mechanisms, decrease trans-cellular active calcium transport and normal calcium absorption by brush-border membrane vesicles, and reduce the synthesis of calcium-binding protein $[20,21]$.

Regarding the serum COMP levels, they were found to be slightly higher in RA patients compared to the normal controls, but the difference is not statistically significant. These was due to RA patient compliance in taking prescribed medication to maintain the patient's quality of life and stabilize disease activity [22]. As serum COMP levels are higher in the early stages of RA, they are used to determine the severity and diagnosis of RA [23]. All of the patients with RA in this study were prescribed disease modifying antirheumatic drugs (DMARDs), nonsteroidal antiinflammatory drugs, and analgesics, which may affect the serum COMP levels. One such DMARD, methotrexate (MTX), modifies the development of joint damage, leading to a decreased COMP level along with improved joint conditions. MTX is proven to modify the progression of joint damage so that decreased the COMP levels with improving joint conditions [23]. There were $66.68 \%$ patients who were only prescribed MTX, while $33.32 \%$ of the patients were prescribed MTX in combination with chloroquine, sulfasalazine, Cyclosporin, or azathioprine. Most patients (90\%) were also prescribed methyl prednisolone, calcium, and folic acid to reduce the MTX side effects [22]. Finally, only $33.33 \%$ of the patients were given analgesics, (paracetamol, ibuprofen, diclofenac sodium, and aspirin). All patients showed good compliance regarding taking the medicines (otherwise they felt pain), which resulted in a not-significantly different COMP level between RA patients and the normal control. These results are consistent with our previous study in Puwarkarta, Indonesia [17]. The goal of appropriate and routine therapy is to maintain the quality of life of the patient and to stabilize disease activity.

Finally, statistical analysis showed that there is no correlation between the serum calcium level and serum COMP level (Fig. 3). This suggests patient compliance in drug consumption as MTX, which is an immunosuppressant, may suppress the progression of RA, resulting in low serum calcium and COMP levels in RA patients.

\section{CONCLUSION}

There is no correlation between serum calcium levels and serum COMP levels in RA patients $(\mathrm{p}=0.967$ and $\mathrm{rho}=0.006)$. Further studies are required regarding the correlation of serum calcium and COMP levels in RA patients who have not been prescribed and are not currently taking any other medicine.

\section{REFERENCES}

1. Schett G, Hayer S, Zwerina J, Redlich K, Smolen JS. Mechanisms of disease: The link between RANKL and arthritic bone disease. Nat Clin Pract Rheumatol 2005;1(1):47-54.
2. Cross M, Smith E, Hoy D, Carmona L, Wolfe F, Vos T, et al. The global burden of rheumatoid arthritis: Estimates from the global burden of disease 2010 study. Ann Rheum Dis 2014;73(7):1316-22.

3. Nainggolan O. Prevalensi dan determinan penyakit rematik di Indonesia. Maj Kedokt Indones 2009;59(12):588-94.

4. Vittecoq O, Pouplin S, Krzanowska K, Jouen-Beadem F, Menard JF, Gayet A, et al. Rheumatoid factor is the strongest predictor of radiological progression of rheumatoidarthritis in a three-year prospective study in community-recruited patients. Rheumatology 2003;42:939-46

5. Tseng S, Reddi AH, Di Cesare PE. Cartilage oligomeric matrix protein (COMP): A biomarker of arthritis. Biomark Insights 2009;4:33-44.

6. Vilím V, Voburka Z, Vytásek R, Senolt L, Tchetverikov I, Kraus VB, et al. Monoclonal antibodies to human cartilage oligomeric matrix protein: Epitope mapping and characterization of sandwich ELISA. Clin Chim Acta 2003;328(1-2):59-69.

7. Esdaile JM, Goicochea M, Lacaille D. Comorbidity in rheumatoid arthritis. In: Hochberg MC, Silman AJ, Smolen JS, Weinblatt ME, Weisman MH, editors. Rheumatoid Arthritis. Philadelphia, PA: Mosby Elsevier; 2009. p. 68-71.

8. NIH (National Institutes of Health). What People With Rheumatoid Arthritis Need to Know about Osteoporosis; 2016. Available from: https://www.niams.nih.gov/Health_Info/Bone/Osteoporosis/ Conditions_Behaviors/Rheum_Arthritis_and_Osteop_4-16.pdf. [Last cited on 2016 Dec 20].

9. Saptarini NM, Wibowo MS, Gusdinar T. Correlation study of age, disease duration, and erythrocyte sedimentation rate among the indonesian rheumatoid arthritis patients. Int $\mathrm{J}$ Pharm Pharm Sci 2015;7(11):274-7.

10. Aletaha D, Neogi T, Silman AJ, Funovits J, Felson DT, Bingham $\mathrm{CO}^{\text {rd }}$, et al. 2010 Rheumatoid arthritis classification criteria. Arthritis Rheum 2010;62:2569-81.

11. Spare PD. A stable murexide reagent for the estimation of calcium in micro quantities of serum. Clin Chem 1964;10(8):726-9.

12. Samanci N, Ozdem S, Akbas H, Mutlu D, Gultekin M, Arman M, et al. Diagnostic value and clinical significance of anti-CCP in patients with advanced rheumatoid arthritis. J Natl Med Assoc 2005;97(8):1120-6.

13. Kashefi S, Lee SM, Mallaysamy S, Thunga G. Demographic, clinical characteristics and drug prescription pattern in patients with rheumatoid arthritis in south Indian tertiary care hospital. Int J Pharm Pharm Sci 2016;8(8):251-7.

14. Cutolo M, Wilder RL. Different roles for androgens and estrogens in the susceptibility to autoimmune rheumatic diseases. Rheum Dis Clin North Am 2000;26(4):825-39.

15. Salem ML. Estrogen, a double-edged sword: Modulation of TH1- and TH2-mediated inflammations by differential regulation of $\mathrm{TH} 1 /$ TH2 cytokine production. Curr Drug Targets Inflamm Allergy 2004;3(1):97-104.

16. Setiyohadi B, dan Metabolisme Tulang S. In: Sudoyo AW, Setiyohadi B, Alwi I, Simadibrata M, dan Setiati S, editors. Ilmu Penyakit Dalam Jilid II. $4^{\text {th }}$ ed. Jakarta: Pusat Penerbitan Departemen Ilmu Penyakit Dalam Fakultas Kedokteran Universitas Indonesia; 2006.

17. Saptarini NM, Wibowo MS, Gusdinar T. Erythrocyte sedimentation rate as an indicator of compliance of rheumatoid arthritis patients: A case study in west java, Indonesia. Mahidol Univ J Pharm Sci 2016;43(2):55-62.

18. Reid DM, Kennedy NS, Smith MA, Tothill P, Nuki G. Total body calcium in rheumatoid arthritis: Effects of disease activity and corticosteroid treatment. Br Med J (Clin Res Ed) 1982;285(6338):330-2.

19. Walwadkar SD, Suryakar AN, Katkam RV, Kumbar KM, Ankush RD. Oxidative stress and calcium-phosphorus levels in rheumatoid arthritis. Indian J Clin Biochem 2006;21(2):134-7.

20. Patschan D, Loddenkemper K, Buttgereit F. Molecular mechanisms of glucocorticoid-induced osteoporosis. Bone 2001;29:498-505.

21. Hoenderop JG, Nilius B, Bindels RJ. Calcium absorption across epithelia. Physiol Rev 2005;85(1):373-422.

22. Schuna AA. Rheumatoid arthritis. In: Dipiro JT, Talbert RL, Yee GC, Matzke GR, Wells BG, Posey LM, editors. Pharmacotherapy: A Pathophysiologic Approach. $7^{\text {th }}$ ed. Singapore: McGraw-Hill Medical; 2007.

23. Lindqvist $\mathrm{E}$, Eberhardt $\mathrm{K}$, Bendtzen $\mathrm{K}$, Heinegård $\mathrm{D}$, Saxne $\mathrm{T}$. Prognostic laboratory markers of joint damage in rheumatoid arthritis. Ann Rheum Dis 2005;64(2):196-201. 